\title{
Review on Use of Bioactive Compounds in Some Spices in Food Preservation
}

\author{
Daniel Asfaw \\ Department of Food Science and Nutrition, Wollega University, Ethiopia
}

\begin{abstract}
Spices contain chemical substances such as polyphenols, quinines, flavonols/flavonoids, alkaloids, polypeptides or their oxygen-substituted derivatives. These bioactive compounds are used in food preservation through their antioxidants and antimicrobials activities. The bioactive compounds extracted from them prevent the oxidation of different meat products, oils and dairy products. These compounds also used for increasing shelf life of meat and meat products, milk and milk products, and fruits and fruit products through killing or retarding the growth of both pathogenic and spoilage microorganisms. In addition, they are used as insecticides which provide an opportunity to replace the synthetic compounds which affect human health. Generally, because of their preventing ability and health benefits, bioactive compounds found in spices can be used in food industries as preservative substances.
\end{abstract}

Keywords: Spices, Bioactive compounds, Antioxidants, Antimicrobials, Food preservation

DOI: $10.7176 / F S Q M / 87-02$

Publication date:May $31^{\text {st }} 2019$

\section{Introduction}

Spices origin has been known to date back to ancient times in Egypt as valuable trade items. The advantage of these spices increasing in Middle East and spread to the Mediterranean and Europe. Now day spices top ten producing countries as at FAO (2011) report were India, Bangladesh, Turkey, China, Pakistan, Iran, Nepal, Colombia, Ethiopia and Sri Lanka. Ethiopia is a homeland for many spices, such as korarima (Aframonum korarima), long red pepper, black cumin, white cumin/bishops weed, coriander, fenugreek, turmeric, sage, cinnamon and ginger (International Trade Centre, 2010).

Spices could be obtained from any part of plant as fresh or dried seeds, kernels, bulbs, stalk, roots, barks, leaves, pods or buds. The medicinal value of them, which include leaves (coriander, mint), buds (clove), bulbs (garlic, onion), fruits (red chili, black pepper), stem (cinnamon), rhizomes (ginger), star anise, cinnamon (bark) and other plant parts, have been defined as plant substances from indigenous or exotic origin, aromatic or with strong taste, used to enhance the taste of foods. Spices are important bio-nutrients for both food ingredients and nutritional supplements. Because of this they are said to be pungent or aromatic substances which are used as additives for the purpose of flavoring, coloring and preserving foods (Dalby, 2002; Abishek et al., 2009). However, the use of these spices in food preservation as natural preservative and their advantage over synthetic antioxidants and antimicrobials are not aware. Therefore, the objective of this is to review the use of bioactive compounds in spices in food preservation.

\section{Bioactive Compounds Constituent of Spices}

Spices contain chemical substances such as polyphenols, quinines, flavonols/flavonoids, alkaloids, polypeptides or their oxygen-substituted derivatives (Cowan, 1999; Perumalla and Hettiarachchy, 2011; Negi, 2012). Spices such as ginger contain bioactive compounds such as gingerols, shogaols, paradols and zingerone that produce a 'hot' sensation in the mouth. From three of these compounds, gingerol is the most abundant and active compound in ginger. Curcumin and Piperine are the major bioactive compounds found in turmeric and black pepper, respectively (Kunnumakkara et al., 2009; Li et al., 2011; Puvaca et al., 2014). However, both of them contain other many phytochmicals in which their contents and bioactivities vary depend on species, varieties and geographical conditions.

To date, approximately 235 compounds, primarily phenolics and terpenoids, have been identified from various species of turmeric, including twenty two diarylheptanoids and diarylpentanoids, eight phenylpropenes as well as other phenolics (Li et al., 2011). From those compounds curcuminoids (mostly curcumin) and essential oils (primarily monoterpenes) are the major bioactive constituents showing different bioactivities.

Volatile oil in Nigela Sativa contains active basic components such as thymoquinone, dithymoquinone and thymohydroquinone (Güllü \& Gülcan, 2013; Kaya et al., 2003). Thymoquinone, which is one of the most important bioactive components of $N$. sativa exists as a volatile oil in a proportion of $18.4 \%-24.0 \%$ (Ali \& Blunden, 2003; Burits \& Bucar, 2000; Yüncü et al., 2013). However, other analyses have indicated that the concentration of thymoquinone is $52.6 \mathrm{mg} / 100 \mathrm{~g}$ (Tüfek et al., 2015).

Shan et al. (2014) found that cloves have the highest amount of flavonoids (366.5 as mg per $100 \mathrm{~g}$ ), followed by caraway (171.9), coriander (167.2) and rosemary (37.8). The abundant and most biologically active 
compound in clove is eugenol and that of caraway are carvone and limonene. Deepa et al. (2013) reported that cardamom and coriander were good sources of flavonoid and scavengers of free radicals. Badei et al. (2002) reported that the threshold level (in cookies) of the volatile oils of cardamom and cinnamon was $0.05 \%$, while that for clove volatile oil was $0.075 \%$. The bioactive compounds of essential oils found from cinnamon bark are trans-cinnamaldehyde, eugenol and linalool, which are representative of almost $82.5 \%$ of total compounds (Asimi et al., 2013).

Table 1. Major bioactive compounds in some spices/herbs

\begin{tabular}{|c|c|c|c|}
\hline S.No & $\begin{array}{c}\text { Name of } \\
\text { spices/herbs }\end{array}$ & Major bioactive compounds & References \\
\hline 1 & Ginger & Shogaols, paradols and zingerone & $\begin{array}{l}\text { Choudhari and Kareppa, 2013; Kim et al., } \\
\text { 2002; Wohlmuth et al., } 2005\end{array}$ \\
\hline 2 & Turmeric & $\begin{array}{l}\text { Curcumin, demethoxycurcumin } \\
\text { and curcuminoid }\end{array}$ & $\begin{array}{l}\text { Salem et al., 2014; Sahne et al. 2016; Tajik } \\
\text { et al., } 2008\end{array}$ \\
\hline 3 & Black pepper & $\begin{array}{lll}\begin{array}{l}\text { Piperine, } \\
\text { pyrrolidines }\end{array} & \text { Piperidines } & \text { and } \\
\end{array}$ & Dawid et al., 2012; Puvaca et al., 2014 \\
\hline 4 & Black cumin & $\begin{array}{l}\text { Thymoquinone, dithymoquinone } \\
\text { and thymohydroquinone }\end{array}$ & Güllü \& Gülcan, 2013; Kaya et al., 2003 \\
\hline 5 & Caraway & Carvone and limonene & Sedláková et al., 2003 \\
\hline 6 & Clove & Eugenol & $\begin{array}{l}\text { Pino et al., 2001; Raina et al., 2001; } \\
\text { Zachariah et al., 2005 }\end{array}$ \\
\hline 7 & Cinnamon & $\begin{array}{l}\text { Trans-cinnamaldehyde, eugenol } \\
\text { and linalool }\end{array}$ & Asimi et al., 2013; Tabak et al., 1996 \\
\hline 8 & Cardamom & $\begin{array}{l}\text { Limonene, Cineole and } \alpha \text {-terpinyl } \\
\text { acetates }\end{array}$ & Agbor et al. 2001 \\
\hline 9 & Rosemary & $\begin{array}{l}\alpha \text {-pinene, camphor, cineole and } \\
\text { camphene }\end{array}$ & Derwich, et al. 2011 \\
\hline
\end{tabular}

\section{Antioxidant and Antimicrobial Activities of Bioactive Compounds}

Antioxidants are substances that prevent oxidation of other compounds or neutralize free radicals. Plants such as fruits, vegetables, spices and herbs are rich sources of antioxidants. Antioxidants from spices are a large group of bioactive compounds which consist of flavonoids, phenolic compounds, sulfur-containing compounds, tannins, alkaloids, phenolic diterpenes, and vitamins (Peter, 2004; Charles, 2013; Yesiloglu et al., 2014; Srinivasan et al., 2014; Choi and Cha, 2014; McCormick, 2017). Spices such as turmeric (Curcuma longa), garlic (Allium sativum), ginger (Zingiber officinalis), black cumin (Nigella sativum), clove (Syzygium aromaticum), red pepper (Capsicum annuum) and black pepper (Piper nigrum) contain several natural antioxidant biomolecules either water-soluble or lipid-soluble.

Antimicrobials derived from plants sources are phytochemicals which are important for the proper functioning of the plant. These antimicrobial compounds are helped the plants as defense mechanism to protect them from plant pathogens and other predators. Phytochemicals in spices are broadly grouped into phenolic compounds, terpenoids and essential oils, alkaloids and polypeptides. It is suggested that the hydrophobicity of the essential oils and their components is an important characteristic that enables the essential oils to accumulate in the lipid bilayer of the bacterial cell membrane and mitochondria, disturbing the cell structures and rendering them more permeable (Benchaar et al., 2008; Solorzano-Santos and Miranda-Novales, 2012). 
Table 2. Antioxidant activities of bioactive compounds in spices/herbs

\begin{tabular}{|c|c|c|c|c|}
\hline $\begin{array}{l}\text { Name of } \\
\text { spices/herbs }\end{array}$ & $\begin{array}{l}\text { Bioactive } \\
\text { compounds }\end{array}$ & Their function & $\begin{array}{l}\text { Comparable with synthetic } \\
\text { antioxidant/antimicrobial }\end{array}$ & References \\
\hline Ginger & Gingerol & $\begin{array}{l}\text { Inhibited hydroxyl } \\
\text { radicals }\end{array}$ & $\begin{array}{l}\text { higher antioxidant activity } \\
\text { than quercetin }\end{array}$ & $\begin{array}{l}\text { Stoilova et al., } \\
2007\end{array}$ \\
\hline $\begin{array}{l}\text { Black } \\
\text { cumin }\end{array}$ & Thymoquinone & As antioxidant activities & $\begin{array}{l}\text { Higher than butylated } \\
\text { hydroxyanisole and } \\
\text { butylated hydroxytoluene }\end{array}$ & $\begin{array}{l}\text { Singh et al., } \\
\text { 1998; Kapoor } \\
\text { et al., } 2010\end{array}$ \\
\hline Cinnamon & Cinnamaldehyde & $\begin{array}{l}\text { Scavengers of peroxide } \\
\text { radicals }\end{array}$ & $\begin{array}{l}\text { Comparable to synthetic } \\
\text { antioxidants }\end{array}$ & $\begin{array}{l}\text { Shahid et al., } \\
\text { 2018; Wu et } \\
\text { al., 1994; }\end{array}$ \\
\hline Clove & $\begin{array}{l}\text { Eugenol and } \\
\text { eugenyl acetate }\end{array}$ & $\begin{array}{l}\text { Antioxidant } \\
\text { against hydroxyl radicals } \\
\text { and acts as an iron } \\
\text { chelator }\end{array}$ & $\begin{array}{l}\text { Greater than BHA, BHT, } \\
\text { TBHQ, PG and OG }\end{array}$ & $\begin{array}{l}\text { Ghadermazi et } \\
\text { al., 2017; } \\
\text { Hossain et al., } \\
\text { 2008; Jirovetz } \\
\text { et al., } 2006\end{array}$ \\
\hline N. sativa & $\begin{array}{l}\text { Thymoquinone and } \\
\text { dithymoquinone }\end{array}$ & $\begin{array}{lr}\text { decreases } & \text { lipid } \\
\text { peroxidation } & \text { and } \\
\text { increases } & \text { antioxidant } \\
\text { enzymes } & \end{array}$ & $\begin{array}{l}\text { Greater than synthetic } \\
\text { antioxidants }\end{array}$ & $\begin{array}{l}\text { Yakup, 2007; } \\
\text { Al-Mahasneh } \\
\text { et al., 2008; } \\
\text { Abdulazeez et } \\
\text { al., } 2015\end{array}$ \\
\hline
\end{tabular}

Table 3. Antimicrobial activities of bioactive compounds in spices/herbs

\begin{tabular}{|c|c|c|c|}
\hline Spices/herbs & $\begin{array}{l}\text { Bioactive } \\
\text { compounds }\end{array}$ & Effective against microorganisms & References \\
\hline Clove & $\begin{array}{l}\text { Eugenol and beta } \\
\text { caryophyllene }\end{array}$ & $\begin{array}{lrr}\text { Antibacterial activity against } & \text { Escherichia } \\
\text { coli, Listeria } & \text { monocytogenes, } & \text { Salmonella } \\
\text { enterica, } & \text { Campylobacter } & \text { jejuni, } \\
\text { Staphylococcus aureus, Bacillus subtilis } \text { and } \\
\text { Saccharomyces cerevisiae }\end{array}$ & $\begin{array}{l}\text { De et al., 1999; Chaieb } \\
\text { et al., 2007; Singh, } 2018\end{array}$ \\
\hline Clove & $\begin{array}{l}\text { Clove oil and } \\
\text { eugenol }\end{array}$ & $\begin{array}{l}\text { Antifungal activity against rye bread spoilage } \\
\text { fungi, Rhizoctonia solani Cladosporium } \\
\text { herbarum, Penicillium glabrum, } P \text {. } \\
\text { expansum, Fusarium verticilloides and } A \text {. } \\
\text { niger }\end{array}$ & $\begin{array}{l}\text { Lee Sang et al., 2003; } \\
\text { Martini et al., 1996; } \\
\text { Suhr and Nielsen, 2003; } \\
\text { Veluti et al., } 2004\end{array}$ \\
\hline Cinnamon & Cinnamaldehyde & $\begin{array}{l}\text { Listeria monocytogenes, Staphylococcus } \\
\text { aureus and Salmonella enterica }\end{array}$ & Shan et al., 2009 \\
\hline $\begin{array}{l}\text { Coriander } \\
\text { leaves and } \\
\text { seeds }\end{array}$ & It's crude extract & $\begin{array}{l}\text { Escherichia coli, Bacillus subtilis and } \\
\text { Salmonella typhi }\end{array}$ & Elgayyar et al., 2001 \\
\hline Ginger & It's crude extract & $\begin{array}{l}\text { Staphylococcus aureus, Streptococcus } \\
\text { pyogenes; E. coli and strengthening immune } \\
\text { system of fish }\end{array}$ & $\begin{array}{l}\text { Awad \& Awaad, 2017; } \\
\text { Sebiomo et al., 2011; } \\
\text { Sikrodia et al., 2018; } \\
\text { Snuossi et al., 2016 }\end{array}$ \\
\hline Garlic & It's crude extract & Proteus mirabilis and Escherichia coli & Petropoulos et al., 2018 \\
\hline
\end{tabular}

\section{Bioactive Compounds in Preventing Food Oxidation}

Oxidation is one of the major factors in food deterioration and reduces its nutritional quality during processing and storage time. Moreover, the free radicals produced from oxidation process are dangerous for human health. However, addition of antioxidants is a useful way to prevent the formation of these harmful compounds. In recent years, synthetic antioxidants such as Butylated hydroxyanisole (BHA), Butylated hydroxytoluene (BHT), tertiary butyl hydroquinone (TBHQ) and propyl galates have been widely used in food industry (Stoilova et al., 2007). However, they have been reported to have demonstrated various adverse effects on the human health including allergy, headache, asthma, cancer and dermatitis (Bondi et al., 2017; Lobo et al., 2010; Shasha, 2014). In contrast natural antioxidants do not have harmful effect and also can improve human health compared to synthetic antioxidants (Bober et al., 2018; Gao et al., 2012; Karaman et al., 2014; Pokorny et al., 2001; Segura Campos et al., 2015).

Spices represent a potent tool for the food industry, thanks to their natural properties (Hyldgaard et al., 
2012). Indeed spices possess antioxidant capacity, mainly due to the presence of phenolic compounds. They exhibit antioxidant property by scavenging free radicals, chelating transition metals, quenching of singlet oxygen, and enhancing the activities of antioxidant enzymes (Rubió et al., 2013).

Alex and Eagappan, (2017) studied on the empirical effect of spices and herbs in the shelf life of dried indian anchovy fish. They concluded that the indigenous spices used, such as black pepper, turmeric and ajwain had chemical preservative and antioxidant properties. Among the three spices, black pepper in combination with ajwain was found to have the most effective preservation potential of sun-dried fish during storage. Essential oils (OEs) of clove used as a natural antioxidant significantly reduced the oxidation of soybean oil and replaced synthetic antioxidants to increase the safety of food systems (Ghadermazi et al., 2017). The antioxidant activity of clove bud extract and its major aroma components, eugenol and eugenyl acetate, were the most effective for retarding lipid oxidation and presented the highest antioxidant activity in raw pork (Shan et al., 2009).

The addition of rosemary or marjoram EOs at a concentration of $200 \mathrm{mg} / \mathrm{kg}$ in beef patties has been shown to reduce lipid oxidation, due to the EOs' antioxidant properties, thus improving the flavour of the patties (Mohamed and Mansour, 2012). It suggested that addition of coriander leaves to food would increase the antioxidant content and may have potential as a natural antioxidant and thus inhibit unwanted oxidation processes (Wangensteen et al., 2004). Shahid et al. (2018) did on the antioxidant capacity of cinnamon extract for palm oil stability. They concluded that the cinnamon extract proved effective in reducing the lipid oxidation of palm oil and it can be successfully used in place of synthetic antioxidants in food preparations.

Grains of Black pepper and the essential oil obtained from them contain compounds that have antimicrobial activity. It is a source of natural antioxidants that stop rancid fats, which is the task of a natural preservative (Abdulazeez et al., 2015). It is proposed that the $N$. sativa extract grown in Tunisia can be used as a natural antioxidant in in vitro and ex vitro environments, and as a food additive to prevent the organoleptic deterioration that occurs due to free radicals (Soumaya et al., 2012). Cardamom incorporated yoghurt had the highest antioxidant activity as measured by DPPH assay (Vijaylakhshmi et al. 2014).

\section{Bioactive Compounds in Preventing Food Spoilage}

Microbial pathogens in food may cause spoilage and contribute to food borne disease incidence, and the emergence of multidrug resistant and disinfectant resistant bacteria-such as Staphylococcus aureus $(S$. aureus), Escherichia coli (E. coli), and Pseudomonas aeruginosa ( $P$. aeruginosa) have increased rapidly, causing the increase of morbidity and mortality (Miladi et al., 2016). Weak acids such as benzoic and sorbic acids (Brul and Coote, 1999), which are commonly applied in food industry as chemical preservatives to increase the safety and stability of manufactured food products on its whole shelf-life by controlling pathogenic and spoilage foodrelated microorganisms (De Souza et al, 2005), can result in the development of microbiological resistance (Silva and Domingues, 2017) and are restricted in many countries (Madsen, et al. 1995).

The search for cheap, non-toxic and natural food preservatives which could be used safely and effectively is an important factor for future food industry. Spices are natural sources having antioxidant and antimicrobial activity that offer an opportunity to replace synthetic preservatives in food, such as nitrates, which have been claimed to possess negative effect on human health (Anand and Sati, 2013). Combinations of probiotics with spices may provide further therapeutic properties. In-vitro studies that tested spices on the growth of selected probiotics showed that spices significantly enhanced the growth of probiotics while inhibiting pathogens (Be et al. 2009). Compounds isolated from different spices shows positive antimicrobial activity against some of the most common microorganisms that affect the food quality and decrease the shelf life of food (Tajkarimi. et al. 2010).

The use of spices EOs as natural preservatives in food industries meets the current consumer trends of "green" "biological", "natural" and "no chemicals added" labels. The FDA (Food and Drug Administration) treats antimicrobial agents of natural origin as GRAS (Generally Recognized As Safe) type products, including plant products from which essential oils (EOs), oleoresins and natural extracts, as well as their distillates, are obtained (Burt, 2004; Newberne et al., 2000; Sauceda, 2011).

\section{Meat and Meat Products}

It has been shown that plant extracts are useful for reduction of pathogens associated with meat products. The application of thyme and cinnamon EOs in ham has been shown to significantly decrease the L. monocytogenes population (Dussaul et al., 2014). The shelf-life of mortadella and bologna sausages has been extended with the use of rosemary/thyme and oregano EOs, respectively (Viuda-Martos et al., 2010). García-Díez et al. (2016) reported the improved safety of dry-cured sausages through the antibacterial effect of garlic and oregano EOs against Salmonella spp., L. monocytogenes and S. aureus. At concentrations of $0.5 \%$ and $1 \%$ clove EO restricted the growth of L. monocytogenes in meat at both $30^{\circ} \mathrm{C}$ and $7{ }^{\circ} \mathrm{C}$ (Vrinda Menon and Garg, 2001). In another study clove, cinnamon, cumin and oregano are effective against inoculated microorganisms on meat, particularly against gram positive and gram negative bacteria (Souza et al., 2006; Sema et al., 2007; Celikel and Kavas, 


\section{8).}

Combined use of EOs and starter cultures in the manufacture of traditional Chinese smoked horsemeat sausages showed that both EOs of spices (cinnamon, cloves, ginger and anise) and starter cultures (L. sakei and $S$. xylosus) inhibited the accumulation of biogenic amines, namely tryptamine, putrescine, cadaverine, histamine and tyramine, and the growth of enterobacteria. It is noteworthy that the inhibitory effects of EOs were stronger than those of starter cultures. Additionally, the synergistic effects between EOs and starter cultures against the accumulation of the above mentioned biogenic amines and the growth of enterobacteria were observed (Lu et al., 2015).

Krisch et al. (2010) conducted comparative study to investigate the antimicrobial effect of commercial herbs, spices and essential oils (fresh and dried garlic, onion, thyme, marjoram, and oregano) in minced pork. While fresh spices showed weak or no inhibition on viable cells of minced pork, some effects of essential oils were observed. Best shelf life values were obtained for pork meat added with garlic and marjoram oil. Antimicrobial activity studies of garlic oil against bacterial isolates from carp showed that, it had the strongest antimicrobial activities, followed by iso-eugenol, eugenol and then citral for increasing the shelf life of carp fillets, respectively (Mahmoud et al., 2007). Basil, clove, garlic, horseradish, marjoram, oregano, rosemary, and thyme have been used successfully to implement hurdle technology for protecting seafood from the risk of Vibrio parahaemolyticus contamination (Yano et al., 2006). A synergistic effect of treatment with anodicelectrolyzed $\mathrm{NaCl}$ solution, combined with eugenol and linalool, has been found to enhance shelf-life extension of coated semi-friedtuna (Abou-taleb and Kawai, 2008).

Hernández-Ochoa et al. (2014) studied on use of essential oils and extracts from spices in meat protection. The results showed that the essential oils with functional extracts were used on meat samples at three different concentrations: $750,1,500$ and $2,250 \mu \mathrm{L}$. The cumin essential oil produced a reduction of $3.78 \mathrm{log} \mathrm{UFC} / \mathrm{g}$ with the application of $750 \mu \mathrm{L}$, the clove essential oil produced a reduction of $3.78 \mathrm{log} \mathrm{UFC} / \mathrm{g}$ with the application of $2,250 \mu \mathrm{L}$ and the cumin and clove functional extracts got a reduction of $3.6 \log \mathrm{UFC} / \mathrm{g}$. A relevant preservation effect for fresh chicken breast meat, stored at $4^{\circ} \mathrm{C}$, was obtained by dipping meat in oregano oil, prior to packaging under MAP (Chouliara et al., 2007). Shelf life of carp fillets was extended fourfold by application of combined carvacrol + thymol with some other additives, compare to sterile $0.2 \%$ agar solution as a control (Mahmoud et al., 2007).

\section{Dairy Products}

Recently, some studies have recorded the efficacy of natural compounds, alone or in combination with other preservation methods, when directly applied to milk (Cava et al., 2007) or to cheese by spraying, immersing, or dusting the products. In line of this idea, Cinnamon, cardamom and clove oils inhibit the growth of yoghurt starter cultures more than mint oil; however, in other study mint oil was effective against Salmonella enteritidis in low-fat yoghurt (Burt, 2004).

The antimicrobial efficacy of the different EOs in dairy products can be influenced by several factors, such as the chemical composition of these products, the concentration in which the oils are used and the microorganisms that are intended to be reduced or eliminated. Comparing the anti-microbial effect of clove, cinnamon, bay and thyme EOs in different concentrations $(0.1 \%, 0.5 \%$ and $1 \%)$ in low-fat and full-fat soft cheese, Smith-Palmer et al. (2001) found that $1 \%$ was the most effective concentration for all EOs. The antiListeria monocytogenes effect was more pronounced in the low-fat cheese, but clove EO at $1 \%$ was more effective in the two types of cheese. This essential oil, at the same concentration, was more active against Salmonella Enteritidis in full-fat cheese than in low-fat cheese. When used at a concentration of $0.5 \%$, the population of Salmonella Enteritidis recovered in the low-fat cheese, but not in full-fat cheese.

In another study clove EO $(0.5 \%$ and $1 \%)$ restricted the growth of $L$. monocytogenes in cheese both at $30^{\circ} \mathrm{C}$ and $7^{\circ} \mathrm{C}$ (Vrinda et al., 2001).

A new dairy product "Karishcum" obtained by adding Curcuma Longa (Curcumin or Turmeric) to classic Karish cheese at a rate of $0.3 \%(\mathrm{w} / \mathrm{v})$ was realized in a study conducted by Hosny et al. (2011). A primary experiment was done to determine the correct percentage of Curcumin addition to cheese milk to get a good taste and a long shelf life. The behavior of pathogenic bacteria in the artificially contaminated product during cold storage for 14 days revealed that addition of the extract $(0.3 \%)$ determined a reduction of bacterial counts of about $1 \log$ of S. typhimurium and two $\log$ of P. aeurogenosa and E. coli 0157:H7.

\section{Fruits and Fruit Products}

Different studies have demonstrated the effectiveness of essential oils and their active compounds to control or inhibit the growth of pathogenic and spoilage microorganisms in both fresh-cut fruit and fruit juices. With the support of this idea, Raybaudi-Massilia et al. (2009) incorporated active compounds of herbs and spices into an alginate-based edible coating and applied on fresh-cut apples where they found a high effectiveness for reducing populations of inoculated E. coli $\mathrm{O} 157: \mathrm{H} 7$ during storage time. 
Recently, the idea of using the potential antimicrobial effect of essential oils (Eos) has served as a basis for the development of innovative approaches to increase shelf-life of fresh-cut fruits and vegetables, referred to as minimally processed (MP) products (Patrignani et al., 2015), such as the use of EOs in addition to edible films (Maria et al., 2012). The more enlightened consumers show great interest in acquiring MP products, "easy to eat", and at the same time seeking to ensure that these products correspond to the concept of clean label, natural and environmentally "friendly".

Raybaudi-Massilia et al. (2008) investigated the combined effects of malic acid and essential oils of cinnamon, palmarosa, and lemongrass (0.3 and $0.7 \%)$ and their main active compounds on microbiological and physicochemical shelf-life of fresh-cut melon. The active compounds were incorporated into an alginate-based edible coating. Melon pieces were inoculated with a $S$. enteritidis $(108 \mathrm{CFU} / \mathrm{ml})$ culture before applying the coating. The incorporation of essential oils or their active compounds into the edible coating prolonged the microbiological shelf-life by more than 21 days. Recently, Campos et al. (2016) using thyme and sage EOs, in strawberries, in the head space of the package, observed the decreasing in the amount of fungi existing with these treatments, when compared with the control samples.

\section{Use of Bioactive Compounds in Active Food Packaging}

In packaged foods, growth and survival of common spoilage and pathogenic microorganisms are affected by a variety of intrinsic factors, such as $\mathrm{pH}$ and presence of oxygen or by extrinsic factors associated with storage conditions, including temperature, time, and relative humidity (Singh et al., 2003; Lòpez-Malo et al., 2005; Rydlo et al., 2006). So, to prevent growth of spoilage and pathogenic microorganisms in packed foods, several chemical preservation techniques have been used in the food industry as these authors reported (Davidson and Taylor, 2007; Farkas, 2007) and not only this, but also different alternatives methods like combination of natural and chemical preservatives have been also utilized.

Nowadays, smart packaging has gained increasing attention, for example, antimicrobial packaging, which can be applied to extend the shelf life of food and products (Appendini and Hotchkiss 2002; Quintavalla and Vicini 2002). Active packaging incorporated with natural extracts is a promising technology to extend shelf life of perishable food. The addition of bioactive compounds with antioxidant/antimicrobial properties directly to food or packaging materials depends primarily on their activity against the targeted microorganisms and oxidative degradation, and their ability to be released at controlled rate during storage and distribution, resulting in extension of food shelf-life (Manzanarez-L'opez et al., 2011).

Many active packaging materials have been developed in the last few years with bioactive compounds extracted from spices and herbs. Typically, in antimicrobial and antioxidant packaging systems, additives are incorporated in different ways (G'omez-Estaca et al., 2014; Manso et al., 2015). The use of spice extracts as active agents in food packaging has been suggested and studied since they provide antioxidant and antimicrobial properties to packaging materials (Sadaka et al., 2014) acting as potential alternatives to food synthetic preservatives (G'omez-Estaca et al., 2014).

The extraction method selected to obtain EOs from spices plays a key role in their composition and final quality, modifying their antimicrobial activity. Nevertheless, the current use of EOs extracted from spices in food packaging is still limited by their volatility and low stability against oxygen and light during processing and storage. Microencapsulation technologies have emerged as a promising alternative to control the release of EOs onto food surfaces and to increase stability against environmental factors.

Pires et al. (2009) developed a microbial sachet incorporated with allyl isothiocyanate. Its efficiency was tested against yeasts, molds, Staphylococcus sp. and psychrotrophic bacteria in sliced mozzarella cheese stored at $12^{\circ} \mathrm{C} \pm 2{ }^{\circ} \mathrm{C}$. A reduction of $3.6 \mathrm{log}$ cycles was observed in yeasts and molds counts in the mozzarella packed with antimicrobial sachet over 15 days of storage time. Ramos et al. (2012) reported the development of antimicrobial active films based on polypropylene by incorporating thymol and carvacrol at three different concentrations (4, 6 and $8 \mathrm{wt} \%$ ) demonstrating their potential to be used as active additives.

Ojagh et al. (2010) reported that the use of a coating with chitosan and cinnamon essential oil improved trout fillet shelf life (16 days vs 10 days of the control) and in particular it enhanced texture, odor, and color. Similar results were also obtained for trout fresh fillets coated with gelatin enriched with cinnamon oil $(1 \%$, $1.5 \%$, and $2 \%$ ). In particular, experimental data indicated that the active coating can be suitable for preserving the fillets and maintain quality to an acceptable level (Andevari and Rezaei, 2011).

New active packaging materials consisting of self-adhesive PP labels with cinnamon EOs inside PET trays were used to extend the shelf-life in late maturing peach fruits. Authors reported the high decrease in the number of infected fruits after 12 days at room temperature when the active label was used $(13 \%)$, in comparison with the non-active packaged peaches $(86 \%)$. An active packaging with cinnamon essential oil combined with MAP was also tested to increase the shelf life of gluten-free sliced bread. Results showed that the active packaging is better than MAP to increase product shelf life because it inhibited microbial growth while maintaining the sensory properties of the gluten-free bread (Gutiérrez et al., 2011). 
Victor et al. (2018) studied on shelf life assessment of fresh poultry meat packaged in novel bionanocomposite of chitosan/montmorillonite incorporated with ginger essential oil. The results showed that when compared to unwrapped poultry meat, samples wrapped in the bionanocomposites showed a reduction in microorganisms count of 1.2-2.6 log CFU/g, maintained color and $\mathrm{pH}$ values and thiobarbituric acid reactive substances (TBARS) index increased at a lower rate, extending fresh poultry meat shelf life. The incorporation of ginger EO enhanced the biopolymer activity, by reducing lipid oxidation and microbiological growth of the poultry meat.

A mixture of cinnamon and clove EOs was found to have a good potential to inhibit growth of spoilage fungi, yeasts and bacteria usually found at intermediate moisture foods. EOs extracted from them were studied with successful incorporation into natural and synthetic polymers, providing bioactive properties to films (Sadaka et al., 2014). Some increase in the antimicrobial stability with the decrease in cinnamon EOs release rate was observed for gelatin films incorporated with cinnamon EO nanoliposomes (Wu et al., 2015). In other study, Kechichian et al. (2010) evaluated the antimicrobial effect of cassava starch films with clove and cinnamon powders in contact with bread slices. They concluded that the antimicrobial effect of this combination of spices could not be clearly assessed since water activity of the bread slices increased considerably during storage, resulting in good conditions for microorganisms' proliferation.

Different authors tested a new package, with grapes wrapped with two distinct films, with the addition of a mixture of eugenol, thymol and carvacrol, and observed that microbial counts were drastically decreased as well as lower occurrence of berry decay (Valero et al., 2006; Guillén et al., 2007). Also other works on 'Crimson Seedless' table grapes, using MAP and eugenol, thymol or menthol inside the packages, showed that counts for yeasts and moulds were significantly reduced in the grapes' packages with natural antimicrobial compounds. Valero et al. (2006) tested table grapes on MAP conditions and active packaging by adding eugenol or thymol and obtained reduced losses of quality, considering sensory, nutritional and functional properties, and also lower spoilage counts, in active packaging with added EO.

Munhuweyi et al. (2017) investigated the in vitro and in vivo inhibitory effects of chitosan EOs, with different concentrations of lemongrass, cinnamon, and oregano oils, using vapour emission and direct coating against Botrytis sp., Penicillium sp. and Pilidiella granati pathogens of pomegranate fruit. Chitosan film incorporated with oregano EO had the highest antifungal activity, followed by cinnamon and lemongrass EOs. The inhibitory effect was higher for fruit directly dipped into the chitosan-EO emulsions than those exposed to vapour.

Other strategies to incorporate EOs into water-soluble polymers to form antimicrobial films have been reported. Otoni et al. (2014) prepared coarse emulsions (1.3-1.9 mm diameter) and nanoemulsions (180-250 nm diameter) of clove bud EOs through low-speed mixing and ultrasonication, respectively, to be incorporated into methylcellulose matrices. They observed that droplet size reduction provided further improvement in antimicrobial properties against yeasts and moulds in sliced bread. In addition, low EOs contents might be used if encapsulated in smaller particles to keep antimicrobial efficiency.

\section{Insecticide Activities of Bioactive Compounds}

In developing countries food grains are losses through insect infestation, especially during storage time (Dubey et al., 2008; Talukder et al., 2004). Losses caused by insects include not only the direct consumption of kernels, but also accumulation of by-products. High levels of the insects detritus may result in grain that is unfit for human consumption and loss of the food commodities, both, in terms of quality and quantity. Insect infestationinduced changes in the storage environment may cause warm moist "hotspots" that provide suitable conditions for storage fungi that cause further losses.

The increasing serious problems of resistance and residue to pesticides and contamination of the biosphere associated with large-scale use of broad spectrum synthetic pesticides have led to the need for effective biodegradable pesticides with greater selectivity. This awareness has created a worldwide interest in the development of alternative strategies, including the discovery of newer insecticides (Dayan et al., 2009).

Natural pesticides are active substances derived from plants and are often used for pest management. Many plant extracts show a broad spectrum of activity against several pests and pose little threat to human health and the environment. Therefore, they have long been touted as attractive alternatives to synthetic pesticides for pest control. Moreover, plant essential oils or their constituents have a broad spectrum of activity against insect pests, plant pathogenic or other fungi, weeds, and nematodes (Dudai et al., 1999; Isman, 2000). Natural products showing activity against pests have been and are still being explored for possible production of commercially available natural products that can be effective on certain pests, selective in crops, non-toxic for the user, easily biodegradable, and that can be locally and easily produced, especially by farmers who usually cannot afford expensive synthetic pesticides.

The characteristic flavours and odours emanating from the volatile oils of spices are known to have various effects on insect pests, including stored insects (Shayya et al., 1991). The uses of these spices as insecticides 
provide an opportunity to replace the synthetic compounds from insecticides by natural alternatives which creates a sustainable market for this kind of products. Therefore with the use of spices as insecticidal natural products, the problem of synthetic pesticides can be solved by the substitution of the synthetic compounds that have been related to harmful health effects with the main active compound of spices which are safe (Eddleston et al., 2006).

Pascual Villalobos (2003) found the potential of plant essential oils against stored-product beetle pests. He reported that coriander oil $(10 \mu \mathrm{l})$ showed activity against the bruchid Callosobruchus maculates, the cereal storage pest. Eugenol, isoeugenol and methyl eugenol cause contact toxicity to the storage pathogens, Sitophilus zeamis and Tribolium costaneum. These compounds have similar toxicity to $S$. zeamis at LD50 $30 \mu \mathrm{g} / \mathrm{mg}$ insect, while for T. costaneum the order of potency is isoeugenol > eugenol > methyl eugenol (Ho et al., 1994; Huang et al., 2002). The volatile oil from cardamom acts as a potential grain protectant by killing various life stages of the stored product insects attacking wheat, e.g. Tribolium castaneum and Sitophilus zeamais, via contact and fumigant action (Huang et al., 2000; Singh et al., 2018). Cinnamon essential oil has also been used as insecticidal (Cheng et al., 2009).

Turmeric has been found effective in controlling certain agricultural and animal pests due to the presence of a variety of bioactive constituents that interfere with insect behavior and growth. The bioactive compounds with insecticidal or pesticidal activity are present in the form of essential oil, those are alpha-Penene, beta-Pinene, Caryophyllene, Eugenol, Limonene turmerones and Ar-turmerone (Duke, 1999; Tripathi et al., 2002). OCoumaric acid and protocatechuic acid are extracted from leaf of C. longa (Duke, 1999). Curcumin (diferuloylmethane) (34\% is responsible for the yellow colour, and comprises curcumin I (94\%), curcumin II $(6 \%)$ and curcumin III $(0.3 \%)$ and it is the most active chemical which acts as natural pesticides (Bhardwaj et al., 2011).

Essential oil extracted from the leaves of turmeric and C. longa showed toxic and growth inhibitory activity, fumigant toxicity, anti-feedent and affects the progeny against stored grain insects. It reduced ovi-position and eggs hatching in cinnamaldehyde and cinnamyl acetate have shown stored grain insects (Sharma et al., 2005). Moreover, turmeric powder in combinations with mustard oil has been reported to protect milled rice against $S$. oryzae (Chander et al., 1991). A combination of $4 \mathrm{ml} / \mathrm{kg}$ of mustard oil and turmeric powder at $20 \mathrm{~g} / \mathrm{kg}$ provided the best protection of milled rice by completely suppressing progeny emergence of $S$. oryzae. In another study, turmeric powder (or grit) provided $63.2 \%$ suppression of progeny of the test insect at $0.5 \%$ level (Chander et al., 2003).

The major constituents of the essential oil of garlic; Allium sativum, methyl allyl disulfide and diallyl trisulfide were to be potent toxicant and fumigants against Sitophilus zeamais and Tribolium castaneum (Huang et al., 2000). The study on other spices reported that the essential oil vapours distilled from anise, cumin, eucalyptus, oregano, and rosemary were also fumigantants and caused $100 \%$ mortality of the eggs of Tribolium confusum and Ephestia kuehniella (Tunc et al., 2000).

Kim et al. (2014) developed laminated films based on PP and LDPE coated with a printing ink containing microencapsulated cinnamon EO to protect food from the Indian meal moth (Plodia interpunctella). Authors reported that these films effectively inhibited the invasion of moth larvae in cookies, milk, chocolate and caramel, acting as insect-resistant films. They observed that microencapsulation decreased the release rate of cinnamaldehyde EO and increased their thermal stability, with no effect on the tensile and moisture barrier properties of the active film.

\section{Conclusion}

The bioactive compounds extracted from spices have high antioxidants and antimicrobial activities. The antimicrobial activities which are extracted from spices are either killing or retarding the growth of spoilage and pathogenic microorganisms. Some of these bioactive compounds also have the ability to destroy the antibiotic resistant microorganisms. Also, the antioxidants which are extracted from spices are comparable to synthetic antioxidants and others are greater than that of synthetic antioxidants. Generally, because of their ability to preventing oxidation, retarding the growth of microorganisms and killing grain store pests; bioactive compounds found in spices are used in food industries and grains storage.

\section{References}

Abdulazeez MA, Sani I, James BD, Abdullahi AS. 2015. Black pepper (Piper nigrum L.) oils. Essential Oils in Food Preservation, Flavor and Safety.;277-285.

Abishek, I., Panchal, S., Poudyal, H., \& Brown, L., 2009. Potential health benefits of Indian spices in the symptons of metabolic synfrome: A review. Indian Journal of Biochemistry \& Biophysics, 46: 461-481.

Abou-taleb, M., Kawai, Y., 2008. Shelf life of semi fried tuna slices coated with essential oil compounds after treatment with anodic electrolyzed $\mathrm{NaCl}$ solution. J. Food Protect., 71(4), 770-774.

Agbor GA, Vinson JA, Oben JE, Ngogang JY. 2001. Comparative analysis of the in vitro antioxidant activity of 
white and black pepper. Nutrition Research. 26:659-663.

Ali, B., \& Blunden, G. 2003. Pharmacological and toxicological properties of Nigella sativa. Phytotherapy Research, 17(4), 299-305.

Alex T., Dr. Eagappan K., 2017. An Empirical Study on the Effect of Spices and Herbs in the Shelf Life of Dried Indian Anchovy Fish. IOSR Journal of Agriculture and Veterinary Science, e-ISSN: 2319-2380, pISSN: 2319-2372. Volume 10, Issue 3, PP 01-07

Allahghadri T, Rasooli I, Owlia P, Nadooshan MJ, Ghazanfari T, Taghizadeh M, et al. 2010. Antimicrobial property, antioxidant capacity, and cytotoxicity of essential oil from cumin produced in Iran. J Food Sci;75:H54-61.

Amagase H, Sakamoto K, Segal ER, Milner JA. 1996. Dietary rosemary suppresses 7,12dimethylbenz(a)anthracene binding to rat mammary cell DNA. J Nutr; 126: 1475-1480.

Anand SP, Sati N. 2013. Artificial preservatives and their harmful effects: looking toward nature for safer alternatives. International Journal of Pharmaceutical Sciences and Research.; 4(7):2496

Andevari, G.T., Rezaei, M., 2011. Effect of gelatin coating incorporated with cinnamon oil on the quality of fresh rainbow trout in cold storage. Int. J. Food Sci. Technol., 46, 2305-2311

Appendini P, Hotchkiss JH. 2002. Review of antimicrobial food packaging. Innov Food Sci Emerg Technol 3:113-26.

Arora, D.S., Jasleen Kaur, J. and Kaur, J. 1999. Antimicrobial activity of spices. International Journal of Antimicrobial Agents 12(3), 257-262.

Asimi A, Sahu NP, Palc AK. 2013. Antioxidant activity and antimicrobial property of some Indian spices. Int J Scient Res Pub.; 3:3-4.

Awad E, Awaad A. Role of medicinal plants on growth performance and immune status in fish. Fish Shellfish Immunol. 2017; 67:40-54.

Badei A., Faheld S., El-Akel A., Mahmoud B. 2002. Application of some spices in flavoring and preservation of cookies: 2-Antimicrobial and sensory properties of cardamom, cinnamon and clove. Dtsch. Lebensm. Rundsch.;98:261-265.

Barbosa-Pereira L., J. M. Cruz, R. Send'on, A. Rodr'1guez Bernaldo de Quir'os, A. Ares, M. Castro-L'opez, M. J. Abad, J. Maroto and P. Paseiro-Losada, 2013. Food Control, , 31, 236-243.

Be K, Gamlath S, Smith S. 2009. In vitro antimicrobial effect of spice extracts on probiotic bacteria. Proceedings of the Nutrition Society of Australia. HEC Press, , 410-14.

Benchaar, C.; Calsamiglia, S.; Chaves, A.V.; Fraser, G.R.; Colombatto, D.; McAllister, T.A.; Beauchemin, K.A. 2008. A review of plant-derived essential oils in ruminant nutrition and production. Anim. Feed Sci. Technol., 145, 209-228.

Bentayeb, K. P. Vera, C. Rubio and C. Nerin, 2009. Anal. Bioanal. Chem., 394, 903-910.

Bhardwaj, R. S., Bhardwaj, K. S., Ranjeet, D. 2011. Curcuma Longa leaves exhibits a potential antioxidant, antibacterial and immunomodulating properties. International J Phytomed. 3:270-278.

Bober Zuzanna, Agnieszka Stępień, David AebisherŁukasz Ożog, Dorota Bartusik-Aebisher, 2018. Review on Medicinal benefits from the use of Black pepper, Curcuma and Ginger. European Journal of Clinical and Experimental Medicine, 16 (2): 133-145

Bondi M., Lauková A., de Niederhausern S, Messi P, and Papadopoulou Ch, 2017. Review on Natural Preservatives to Improve Food Quality and Safety. Journal of Food Quality, Article ID 1090932, 3 pages

Brul S., Coote P. 1999. Preservative agents in foods. Mode of action and microbial resistance mechanisms. Int. J. Food Microbiol.;50:1-17. doi: 10.1016/S0168-1605(99)00072-0. [PubMed] [CrossRef]

Burits, M., \& Bucar, F. 2000. Antioxidant activity of Nigella sativa essential oil. Phytotherapy Research, 14(5), 323-328.

Burt S. 2004. Essential oils: their antibacterial properties and potential applications in foods--a review. Int J Food Microbiol.;94(3):223-53.

Campos T, Barreto S, Queirós R, Ricardo-Rodrigues S, Félix MR, Laranjo M, et al. 2016. Conservação de morangos com utilização de óleos essenciais. . AGROTEC.;18:90-6.

Cava, R., Nowak, E., Taboada, A., \& Marin-Iniesta, F., 2007. Antimicrobial activity of clove and cinnamon essential oils against Listeria monocytogenes in pasteurized milk. Journal of Food Protection, 70(12), 27572763.

Celikel N, Kavas G 2008. Antimicrobial properties of some essential oils against some pathogenic microorganisms. Czech J Food Sci 26:174-181

Chaieb, K., Hajlaoui, H., Zmantar, T., Ben, A., Rouabhia, M., Mahdouani, K. and Bakhrouf, A. 2007. The chemical composition and biological activity of clove essential oil, Eugenia caryophyllata (Syzigium aromaticum L. Myrtaceae): a short review. Phytother. Res. 21: 501506.

Chander, H., Kulkarni, S. G., Berry, S. K. 1991. Effectiveness of turmeric powder and mustard oil as protectants in stored milled rice against the rice weevil Sitophilus oryzae. Int Pest Control. 33:94-97. 
Chander, H., Nagender, A., Ahuja, D. K., et al. 2003. Effect of various plant materials on the breeding of lesser grain borer (Rhyzopertha dominica) in milled rice in laboratory. J. Food Sci. Technol. Mys. 40:482-485.

Charles, D.J. 2013. Antioxidant Properties of Spices, Herbs and Other Sources; Springer: New York, NY, USA,; p. 612 .

Cheng SS, Liu JY, Huang CG, Hsui YR, Chen WJ, Chang ST. 2009. Insecticidal activities of leaf essential oils from Cinnamomum osmophloeum against three mosquito species. Bioresour Technol.; 100:457-64.

Choi, I.S.; Cha, H.S. 2014. Physicochemical and antioxidant properties of black garlic. Molecules, 19, 1681116823. [CrossRef] [PubMed]

Choudhari S.S. and B.M. Kareppa, 2013. Identification of Bioactive Compounds of Zingiber Officinale Roscoe Rhizomes Through Gas Chromatography And Mass Spectrometry. International journal on pharmaceutical research and development. Vol 5(08):016 - 020

Cowan, M.M. Plant products as antimicrobial agents. Clin. Microbiol. Rev. 1999, 12, 564-582.

Dalby, A. (2002). Dangerous tastes; the story of spices. Berkeley University of California press.

Davidson, P.M., Taylor, M.T., 2007. Chemical preservatives and natural antimicrobial compounds, in food microbiology: Fundamentals and frontiers, eds Doyle, P., Beuchat, L.R., Montville, T.J., editors. (Washington, DC: American Society forMicrobiology Press; ), 713-734.

Dayan F. E., Cantrell, and S. O. Duke, 2009. "Natural products in crop protection," Bioorganic and Medicinal Chemistry, vol. 17, no. 12, pp. 4022-4034,.

De, M., De, A.K. and Banerjee, A.B. 1999. Antimicrobial screening of some Indian Spices. Phytotherapy Research 13(7), 616-618.

Debiagi, F., R. K. T. Kobayashi, G. Nakazato, L. A. Panagio and S. Mali, 2014. Ind. Crops Prod., 52, 664-670.

Deepa G, Ayesha S, Nishtha K, Thankamani M. 2013. Comparative evaluation of various total antioxidant capacity assays applied to phytochemical compounds of Indian culinary spices. International Food Research Journal,; 20(4):221-227.

De Souza E.L., Stamford T., Lima E.D., Trajano V.N., Barbosa J.M. 2005. Antimicrobial effectiveness of spices: An approach for use in food conservation systems. Braz. Arch. Biol. Technol.;48:549-558. doi: 10.1590/S1516-89132005000500007. [CrossRef]

Derwich E, Benziane Z, Chabir R. 2011. Aromatic and medicinal plants of morocco: Chemical composition of essential oils of Rosmarinus officinalis and Juniperus Phoenicea,.

Dhuley JN. 1999. Antioxidant effects of cinnamon (Cinnamomum verum) bark and greater cardamom (Amomum subulatum) seeds in rats fed high fat diet. Indian J Exp Biol;37:238-42.

Dorman, H.J.D. and Deans, S.G. 2000. Antimicrobial agents from plants: antibacterial activity of plant volatile oils. Journal of Applied Microbiology 88(2), 308-316.

Dorman, H.J.D., Surai, D. and Deans, S.G. 2000. In vitro antioxidant activity of a number of plant essential oils and phyto constituents. Journal of Essential Oil Research 12, 241-248.

Dubey N. K., B. Srivastava, and A. Kumar, 2008. "Current status of plant products as botanical pesticides in storage pest management," Journal of Biopesticide, vol. 1, no. 2, pp. 182-186,.

Dudai, N., Poljakoff, M. A., Mayer, A. M. 1999. Essential oils as allelochemicals and their potential use as bioherbicides. J. Chem. Ecol. 25:1079-1089.

Duke, J. A. 1999. Dr. Duke's Essential Herbs. Emmaus, Pennsylvania: Rodale Press.

Dussault D, Vu KD, Lacroix M. 2014. In vitro evaluation of antimicrobial activities of various commercial essential oils, oleoresin and pure compounds against food pathogens and application in ham. Meat Science.;96(1):514-20.

Eddleston, M., Eyer, P., Worek, F., Mohamed, F., Senarathna, L., Von Meyer, L., Juszczak, E., Hittarage, A., Azhar, S., Dissanayake, W., Sheriff, M. H., Szinicz, L., Dawson, A. H. and Buckley, N. A. 2006. Differences between organophosphorus insecticides in human selfpoisoning:a prospective cohort study. Lancet 367(9508): 396.

Elgayyar, M., Draughon, F.A., Golden, D.A. and Mount, J.R. 2001. Antimicrobial activity of essential oils from plants against selected pathogenic and saprophytic microorganisms. Journal of Food Protection 64(7), 1019-1024.

Farkas, J., 2007. Physical methods of food preservation, in food microbiology: Fundamentals and frontiers, eds. Doyle, P., Beuchat, L.R., Montville, T.J., editors. (Washington, DC: American Society for Microbiology Press) 685-705

Food and Agriculture Organisation, 2011. Production of spices by countries

Freeman, F., Kodera, Y. 1995. Garlic chemistry: stability of S-(2-propenyl)-2-propene-1-sulfinothiate (allicin) in blood, solvents and simulated physiological fluids. Journal of Agricultural and Food Chemistry, 43,23322338.

Gachkar, L., Davood, Y., Mohammad, B.R., Masood, T., Shakiba, A.A. and Iraj, R. 2007. Chemical and biological characteristics of Cuminum cyminum and Rosmarinus officinalis essential oils. Food Chemistry 
102(3), 898-904.

Gao W, Chan JY, Wei WI, Wong TS. 2012. Anti-cancer effects of curcumin on head and neck cancers. Anticancer Agents Med Chem;12:1110-16.

García-Díez J, Alheiro J, Pinto AL, Soares L, Falco V, Fraqueza MJ, et al. 2016. Behaviour of food-borne pathogens on dry cured sausage manufactured with herbs and spices essential oils and their sensorial acceptability. Food Control.;59:262-70.

Ghadermazi, R., Keramat, J. and Goli, S.A.H., 2017. Antioxidant activity of clove (Eugenia caryophyllata Thunb), oregano (Oringanum vulgare L) and sage (Salvia officinalis L) essential oils in various model systems. International Food Research Journal 24(4): 1628-1635

G'omez-Estaca J., C. L'opez-de-Dicastillo, P. Hern'andez- Mũnoz, R. Catal'a and R. Gavara, 2014. Trends Food Sci. Technol., , 35, 42-51.

Gowda, N.K.S., Malathi, V. and Suganthi, R.U. 2004. Effect of some chemical and herbal compounds on growth of Aspergillus parasiticus and aflatoxin production. Animal Food Science and Technology 116, 281-291.

Guillén F, Zapata PJ, Martínez-Romero D, Castillo S, Serrano M, Valero D. 2007. Improvement of the Overall Quality of Table Grapes Stored under Modified Atmosphere Packaging in Combination with Natural Antimicrobial Compounds. Journal of Food Science.;72(3):S185-S90.

Gulcin, I., Sat, I.G., Beydemir, S., Elmastas, M. and Kufrevioglu, O.I. 2004. Comparison of antioxidant activity of clove (Eugenia caryophylata Thunb) buds and lavender (Lavandula stoechas L.). Food Chemistry 87, 393-400.

Güllü, E.B., \& Gülcan, A. 2013. Timokinon: Nigella sativa' nın Biyoaktif Komponenti. Kocatepe Veterinary Journal, 6(1), 51-61.

Gutiérrez, L., Batlle, R., Andújar, S., Sánchez, C., Nerín, C., 2011. Evaluation of antimicrobial active packaging to increase shelf life of gluten free sliced bread. Pack. Technol. Sci., 24, 485-494.

Hernández-Ochoa L. \& Y. B. Aguirre-Prieto \& G. V. Nevárez-Moorillón \& N. Gutierrez-Mendez \& E. SalasMuñoz, 2014. Use of essential oils and extracts from spices in meat protection J Food Sci Technol, 51(5):957-963

Ho, S.H., Cheng, L.P.L., Sim, K.Y. and Tan, H.T.W. 1994. Potential of cloves (Syzygium aromaticum (L.) Merr. and Perry as a grain protectant against Tribolium castaneum (Herbst) and Sitophilus zeamais Motsch. Postharvest Biology and Technology 4, 179-183.

Hosny I. M., El Kholy W. I., Murad H. A., El Dairouty R. K. 2011. Antimicrobial activity of Curcumin upon pathogenic microorganisms during manufacture and storage of a novel style cheese "Karishcum". J. Am. Sci. 7, 611-618

Hossain M.B., N.P. Brunton, C. Barry-Ryan, A.B. Martin-Diana, and M. Wilkinson, 2008. Antioxidant activity of spice extracts and phenolics in comparison to synthetic antioxidants. Journal of Chemistry Vol.1, No.4,751-756

Huang, Y., Lam, S.L. and Ho, S.H. 2000. Bioactivities of essential oil from Elletaria cardamomum (L.) Maton to Sitophilus zeamais Motschulsky and Tribolium castaneum (Herbst). Journal of Stored Products Research 36, 107-117.

Huang Y., S. X. Chen, and S. H. Ho, 2000. "Bioactivities of methyl allyl disulfide and diallyl trisulfide from essential oil of garlic to two species of stored-product pests, Sitophilus zeamais (Coleoptera: Curculionidae) and Tribolium castaneum (Coleoptera: Tenebrionidae)," Journal of Economic Entomology, vol. 93, no. 2, pp. 537-543

Huang, Y., Ho, S.H., Lee, H.C. and Yap, Y.L. 2002. Insecticidal properties of eugenol, isoeugenol and methyleugenol and their effects on nutrition of Sitophilus zeamais Motsch. (Coleoptera: Curculionidae) and Tribolium castaneum (Herbst) (Coleoptera: Tenebrionidae). Journal of Stored Products Research 38, 403412.

Hughes J., R. Thomas, Y. Byun and S. Whiteside, Carbohydr. Polym., 2012, 88, 165-172.

Hyldgaard,M.,Mygind,T.,andMeyer,R.L.2012.Essentialoils preservation:modeofaction,synergies,andinteractionswith food matrixcomponents. Front.Microbiol. 3:12.doi:10.3389/fmicb.. 00012

Innovations in Food Packaging, ed. J. H. Han, Elsevier Academic Press, Canada, 2005.

International Trade Centre, 2010. Spice Sub-sector Strategy for Ethiopia. Addis Ababa, Ethiopia.

Isman, M. B. 2000. Plant essential oils for pest and disease management. Crop. Prot. 19:603-608.

Jayaprakasha, G.K., Negi, P.S., Anandha Ramakrishanan, C. and Sakariah, K.K. 2001. Chemical composition of turmeric oil - a by-product from turmeric oleoresin industry and its inhibitory activity against different fungi. Zeitschrift fur Naturforschung 56c, 40-44.

Jirovetz, L., Buchbauer, G., Stoilova, I., Stoyanova, A., Krastanov, A. and Schmidt, E. 2006. Chemical composition and antioxidant properties of clove leaf essential oil. Journal of Agriculture and Food Chemistry 54(17), 6303-6307. 
Jo H. J., K. M. Park, S. C. Min, J. H. Na, K. H. Park and J. Han, J. Food Sci., 2013, 78, E1713-E1720.

Kapoor IP, Singh B, Singh G, De Heluani CS, De Lampasona MP, Catalan CA. 2010. Chemistry and antioxidant activity of essential oil and oleoresins of black caraway (Carum bulbocastanum) fruits. J Sci Food Agric; 90:385-90.

Karaman, S. “ Toker, O. S. Y“uksel, F. , am, M. C Kayacier, A.and Dogan, M. 2014. "Physicochemical, bioactive, and sensory properties of persimmon-based ice cream: technique for order preference by similarity to ideal solution to determine optimum concentration," Journal of Dairy Science, vol. 97, no. 1, pp. 97-110

Kaya, M.S., Kara, M., \& Özbek, H. 2003. Çörek otu (Nigella sativa) tohumunun insanhücresel bağışıklık sisteminin $\mathrm{CD} 3+, \mathrm{CD} 4+, \mathrm{CD} 8+$ hücreleri ve toplam lökosit sayısı üzerine etkileri. Genel Tip Dergisi, 13, 109-112.

Kechichian V., C. Ditchfield, P. Veiga-Santos and C. C. Tadini, 2010. LWT-Food Sci. Technol., 43, $1088-1094$.

Kikuzaki H, Kawai Y, Nakatani N. 2001. 1,1-Diphenyl-2-picrylhydrazyl radical-scavenging active compounds from greater cardamom (Amomum subulatum Roxb.) J Nutr Sci Vitaminol (Tokyo), 47:167-71.

Kim, H.K., Kim, Y.A., Hwang, S.W. and Ko, B.S. 2002. Quantitative analysis of 6-gingerol in the Zingiberis Rhizoma by processing methods. Korean Journal of Pharmacognosy 33(4), 291-295.

Kim H, Park J, Tak KH, Bu SY, Kim E. 2014. Chemopreventive effects of curcumin on chemically induced mouse skin carcinogenesis in BK5.insulin-like growth factor-1 transgenic mice. In Vitro Cell Dev Biol Anim;50:883-92.

Kim, I.-H. Song, A. Y. Han, J. Park K. H. and S. C. Min, 2014. J. Food Sci., 79, E2023-E2030

Kluth D, Banning A, Paur I, Blomhoff R, Brigelius-Flohe R. 2007. Modulation of pregnane X receptor- and electrophile responsive element-mediated gene expression by dietary polyphenolic compounds. Free Radic Biol Med; 42:315-25.

Kunnumakkara AB, Koca C, Dey S, et al. 2009. Traditional uses of spices: An Overview. In: Aggarwal BB, Kunnumakkara AB, editors. Molecular targets and therapeutic uses of spices Modern Uses for Ancient Medicine. World Scientific Publishing Co Pte Ltd;:1-24.

Lawrence, B.M. 1992. Progress in essential oils. Perfumer and Flavourist 17(4), $42-44$.

Lee, K.G. and Shibamoto, T. (2001) Antioxidant property of aroma extract isolated from clove buds [Syzygium aromaticum (L.) Merr. et Perry]. Food Chemistry 74(4), 443-448.

Lee Sang, Myeong, Jo HyunJin, Kim DongSoo, Kim DoWan, Lee DongWoon, Choo HoYul, and Lee Chongkyn 2003. Effect of clove extract on antifungal activity against Rhizoctonia solani and plant growth. KFRI Journal of Forest Science Seoul 66, 105-111.

Li, C.J., Zhang, L.J., Dezube, B.J. and Crumpacker, C.S. 1993. Three inhibitors of human type 1 immunodeficiency virus long terminal repeat directed gene expression and virus replication. Proceedings of the National Academy of Science (USA) 90, 1839-1842.

Li,.S, W. Yuan, G. Deng, P. Wang, P. Yang, and B. Aggarwal, 2011. "Chemical composition and product quality control of turmeric (curcuma longa L.)," Pharmaceutical Crops, vol. 2, pp. 28-54

Li J. H., Miao J., Wu J. L., Chen S. F. and Q. Q. Zhang, 2014. Food Hydrocolloids, 37, 166-173.

Liakos, I., L. Rizzello, D. J. Scurr, P. P. Pompa, I. S. Bayer and A. Athanassiou, 2014. Int. J. Pharm., 463, 137145.

Lin, J.K., Huang, T.S., Shih, C.A. and Lin, J.Y. 1994. Molecular mechanism of action of curcumin, in food phytochemicals II: teas, spices, and herbs. American Chemical Society 20, 196-203.

Lobo,. V, A. Patil, A. Phatak, and N. Chandra, 2010. "Free radicals, antioxidants and functional foods: impact on human health," Pharmacognosy Reviews, vol. 4, no. 8, pp. 118-126

Lopez, P., Sanchez, C., Batle, B. and Nerin, C. 2005. Solid and vapour phase antimicrobial activities of six essential oils: susceptibility of selected foodborne bacterial and fungal strains. Journal of Agriculture and Food Chemistry 53, 6338-6346.

Lòpez-Malo, A., Maris Alzamora, S., Palou, E., 2005. Aspergillusflavus growth in the presence of chemical preservatives and naturally occurring antimicrobial compounds. Int. J. Food Microbiol., 99, 119-128.

Lu S, Ji H, Wang Q, Li B, Li K, Xu C, et al. 2015. The effects of starter cultures and plant extracts on the biogenic amine accumulation in traditional Chinese smoked horsemeat sausages. Food Control. 50:869-75.

Madsen HL, Bertelsen G. 1995. Spices as antioxidants. Trends in Food Science \& Technology. 6(8):271-277.

Mahmoud, B.S.M., Kawai, Y., Yamazaki, K., Miyashita, K., Suzuki, T., 2007. Effect of treatment with electrolyzed $\mathrm{NaCl}$ solutions and essential oil compounds on the proximate composition, amino acid and fatty acid composition of carp fillets. Food Chem., 101(4), 1492-1498.

Man, Y.B.C. and Jaswir, I. 2000. Effect of rosemary and sage extracts on frying performance of refined, bleached and deodorized (RBD) palm olein during deep-fat frying. Food Chemistry 69: 301-307.

Manso, S. Becerril, R. Ner'1n C. and G'omez-Lus, 2015. R.Food Control, 47, 20-26.

Manzanarez-L'opez F., H. Soto-Valdez, R. Auras and E. Peralta, 2011. J. Food Eng., 104, 508-517. 
Maria DA, Custodia MG, Ana MC, Maria GM. 2012. Edible Coatings Enriched with Essential Oils and their Compounds for Fresh and Fresh-cut Fruit. Recent Patents on Food, Nutrition \& Agriculture.;4(2):114-22.

Martini, H., Weidenborner, M., Adams, S. and Kunz, B. 1996. Eugenol and carvacrol: the main fungicidal compounds in clove and savory. Italian Journal of Food Science 8, 63-67.

Matan N, Rimkeeree H, Mawson AJ, Chompreeda P, Haruthaithanasan V, Parker M. 2006. Antimicrobial activity of cinnamon and clove oils under modified atmosphere conditions. Int $\mathrm{J}$ Food Microbiol. 107(2):180-5.

McCormick. 2017. The History of Spices. Available online: http://www.mccormickscienceinstitute.com/resources/history-of-spices (accessed on 30 May

Miladi H., Zmantar T., Chaabouni Y., Fedhila K., Bakhrouf A., Mandouani K., Chaieb K. 2016. Antibacterial and efflux pump inhibitors of thymol and carvacrol against food-borne pathogens. Microb. Pathog.;99:95100. doi: 10.1016/j.micpath.2016.08.008. [PubMed] [CrossRef]

Mohamed HMH, Mansour HA. 2012. Incorporating essential oils of marjoram and rosemary in the formulation of beef patties manufactured with mechanically deboned poultry meat to improve the lipid stability and sensory attributes. LWT - Food Science and Technology.;45(1):79-87.

Munhuweyi K, Caleb OJ, Lennox CL, van Reenen AJ, Opara UL. 2017. In vitro and in vivo antifungal activity of chitosan-essential oils against pomegranate fruit pathogens. Postharvest Biology and Technology. 129:922.

Mytle, N., Anderson, G.L., Doyle, M.P. and Smith, M.A. 2006. Antimicrobial activity of clove (Syzgium aromaticum) oil in inhibiting Listeria monocytogenes on chicken frankfurters. Food Control 17(1), 102107.

Negi, P.S. 2012. Plant extracts for the control of bacterial growth: Efficacy, stability and safety issues for food application. Int. J. Food Microbiol., 156, 7-17.

Newberne, P.; Smith, R.L.; Doull, J. and Feron, V.J. 2000. GRAS flavoring substances. Food Technology, 54, 66-83.

Ojagh, S.M., Rezaei, M., Razavi, S.H., Hosseini, S.M.H., 2010. Effect of chitosan coatings enriched with cinnamon oil on the quality of refrigerated rainbow trout. Food Chem., 120, 193-198.

Osawa, T., Sugiyama. Y., Inayoshi, M. and Kawakishi. S. 1995. Antioxidative activity of tetrahydro curcuminoids. Bioscience, Biotechnology and Biochemistry 59(9), 1609-1612.

Otoni, C. G. Pontes, E. A. A. Medeiros and N. d. F. F. Soares, J. 2014. Agric. Food Chem., 62, 5214-5219.

Pascual Villalobos, M.J. 2003. Volatile activity of plant essential oils against stored product beetle pests. Advances in stored product protection. Proceedings of the 8th International Working Conference on Stored

Patrignani F, Siroli L, Serrazanetti DI, Gardini F, Lanciotti R. 2015. Innovative strategies based on the use of essential oils and their components to improve safety, shelf-life and quality of minimally processed fruits and vegetables. Trends in Food Science \& Technology. 46(2, Part B):311-9.

Perumalla, A.V.S.; Hettiarachchy, N.S. 2011. Green tea and grape seed extracts-Potential applications in food safety and quality. Food Res. Int., 44, 827-839.

Peter, K.V. 2004. Handbook of Herbs and Spices;Woodhead Publishing Limited: Cambridge, UK, Volume 2.

Petropoulos Spyridon, Ângela Fernandes, Lillian Barros, Ana Ciric, Marina Sokovic, Isabel C.F.R. Ferreira, 2018. Antimicrobial and antioxidant properties of various Greek garlic genotypes. Food Chemistry journal of Elsevier, 245, 7-12

Pino, J.A., Marbot, R., Aguero, J. and Fuentes, V. 2001. Essential oil from buds and leaves of clove (Syzygium aromaticum (L.) Merr. et Perry) grown in Cuba. Journal of Essential Oil Research 13(4), 278-279.

Pires, A.C.S., Soares, N.F.F., Andrade, N.J., Silva, L.H.M., Camilloto, G.P., Bernardes, P.C., 2009. Increased preservation of sliced mozzarella cheese by antimicrobial sachet incorporated with allylisothiocyanate. Braz. J. Microbiol., 40, 1002-1008.

Pokorny, J., Yanishlieva, N. and Gordon, M.H. 2001. Antioxidants in food: practical applications, USA: CRC press.

Puvača Nikola, Dragana Ljubojević, Dragomir Lukač, Miloš Beuković, Ljiljana Kostadinović, Sanja Teodosin, Vidica Stanaćev, 2014. Bioactive Compounds of Garlic, Black Pepper and Hot Red Pepper. XVI International Symposium “Feed Technology”, pp 116-119

Quintavalla S, Vicini L. 2002. Antimicrobial food packaging in meat industry. Meat Sci 62:373-80.

Ragheb, A., Elbarbry, F., Prasad, K., Mohamed, A., Ahmed, M.S., \& Shoker, A. 2008. Attenuation of the development of hypercholesterolemic atherosclerosis by thymoquinone. International Journal of Angiology, 17(04), 186-192.

Raina, V.K., Srivastava, S.K., Aggarwal, K.K., Ramesh, S. and Kumar, S. 2001. Essential oil composition of Cinnamomum zeylanicum Blume leaves from Little Andaman, India. Flavour and Fragrance Journal 16(5), 374-376.

Raybaudi-Massilia, R. M., Mosqueda-Melgar, J., Martín-Belloso, O. 2008. Edible alginate-based coating as 
carrier of antimicrobials to improve shelf-life and safety of fresh-cut melon. Int J Food Microbiol, 121(3): $313-327$.

Raybaudi-Massilia, R.M., Mosqueda-Melgar, J., Sobrino-Lòpez, A., Soliva-Fortuny, R., Martín-Belloso, O., 2009. Use of malic acid and other quality stabilizing compounds to assure the safety of fresh-cut "Fuji" apples by inactivation of Listeria Monocytogenes, Salmonella Enteritidis and Escherichia coli O157, H7. J. Food Saf., 29, 236-252.

Ramos M., A. Beltran, A. Valdes, M. A. Peltzer, A. Jimenez and M. C. Garrigos, J. 2012. Bioequivalence Bioavailability, 5, 154-160.

Rubió,L.,Motilva,M.J.,andRomero,M.P.2013.Recentadvancesinbiologicallyactivecompoundsinherbsandspices:ar eviewofthemosteffective antioxidant andanti-inflammatoryactiveprinciples. Crit.Rev.FoodSci.Nutr. 53,943953. doi:10.1080/10408398.2011.574802

Ruby, A.J., Kuttan, G., Dinesh Babu, K., Rajasekharan, K.N. and Kuttan, R. 1995. Antitumor and antioxidant activity of natural curcuminoids. Cancer Letters 94, 79-83.

Rydlo, T., Miltz, J., Mor, A., 2006. Eukaryotic antimicrobial peptides: promises and premises in food safety. J. Food Sci., 71, 125-135.

Sadaka F., C. Nguimjeu, C. H. Brachais, I. Vroman, L. Tighzert and J. P. 2014. Couvercelle, Innovative Food Sci. Emerging Technol., DOI: 10.1016/j.ifset.2014.03.002.

Sahne Foozie, Maedeh Mohammadi, Ghasem D. Najafpour and Ali Akbar Moghadamnia, 2016. Extraction of Bioactive Compound Curcumin from Turmeric (Curcuma Longa L.) Via Different Routes: A Comparative Study. Pak. J. Biotechnol. Vol. 13 (3) $173-180$

Salem, M., Rohani, S. and Gillies, E.R., 2014. Curcumin, a promising anti-cancer therapeutic: a review of its chemical properties, bioactivity and approaches to cancer cell delivery. Rsc Advances 4:10815-10829.

Sanchez-Bel, P. Egea, I. Pretel, M. T. Flores, F. B. Romojaro F. and Mart'inez-Madrid, M. C., 2011. Food Sci. Technol. Int., , 17, 529-540.

Sauceda ENR. 2011. Uso de agentes antimicrobianos naturales en la conservación de frutas y hortalizas. Ra Ximhai.7(1):153-70.

Sebiomo A, Awofodu AD, Awosanya AO, Awotona FE, Ajayi AJ. 2011. Comparative studies of antibacterial effect of some antibiotics and ginger (Zingiber officinale) on two pathogenic bacteria. $J$ Microbiol Antimicrob.;3(1): 18-22.

Sema, A., Nursel, D. and Süleyman, A. 2007. Antimicrobial activity of some spices used in the meat industry. Bull Vet I Pulawy 51:53-57.

Shahid Muhammad Zia, Hafiza Saima, Adeela Yasmin, Muhammad Tahir Nadeem, Muhammad Imran and Muhammad Afzaal, 2018. Antioxidant capacity of cinnamon extract for palm oil stability. Lipids in Health and Disease, 17:116

Shan B., Cai Y.Z., Brooks J.D., Corke H. 2009. Antibacterial and antioxidant effects of five spice and herb extracts as natural preservatives of raw pork. J. Sci. Food Agric. 89:1879-1885. doi: 10.1002/jsfa.3667. [CrossRef]

Sharma PC, Yelne MB, Dennis TJ. 2005. Database on Medicinal Plants Used in Ayurveda. Central Council for Research in Ayurveda \& Siddha, New Delhi, 420-440.

Shayya, E., Ravid, U., Paster, N., Juven, B., Zisman, U. and Pissarev, V. 1991. Fumigant toxicity of essential oils against four major stored-product insects. Journal of Chemical Ecology 17, 499-504.

Segura Campos, M. R. Ruiz Ruiz, J. Chel-Guerrero, L. and Betancur Ancona, D. 2015. "Coccoloba uvifera (L.)(Polygonaceae) fruit: phytochemical screening and potential antioxidant activity," Journal of Chemistry, vol. 2015,Article ID534954, 9 pages,

Shasha,.D, 2014. "Reversed Phase HPLC-UV Quantitation of BHA, BHT and TBHQ in Food Items Sold in Bindura Supermarkets, Zimbabwe," International Research Journal of Pure and Applied Chemistry, vol. 4, no. 5, pp. 578-584,

Sharma, R. A., Gescher, A. J., Steward, W. P. 2005. Curcumin: The story so far. European Journal of Cancer. 41:1955-1968.

Singh R., 2018. Antimicrobial activity of selected medicinal plants cinnamon and clove. International Journal of Research in Pharmacy and Pharmaceutical Sciences. Volume 3; Issue 5; Page No. 48-50

Sikrodia R., Chhabra D., Audarya S.D. and Sharda R, 2018. Efficacy of Antimicrobial Activity of Aqueous Extract of Garlic (Allium sativum) and Ginger (Zingiber officinale) against Different Bacterial Species. International Journal of Current Microbiology and Applied Sciences ISSN: 2319-7706 Volume 7, Pp 30213025

Silva F., Domingues F.C. 2017. Antimicrobial activity of coriander oil and its effectiveness as food preservative. Crit. Rev. Food Sci. Nutr. 57:35-47. doi: 10.1080/10408398.2013.847818. [PubMed] [CrossRef]

Singh, G., Kapoor, I.P.S., Pandey, S.K. and Singh, G. 1998. Studies on essential oils - XIII: natural antioxidant for sunflower oil. Journal of Scientific and Industrial Research 57(3), 139-142. 
Singh, T.K., Drake, M.A., Cadwallader, K.R., 2003. Flavour of Cheddar cheese: A chemical and sensory perspective. Comp. Rev. Food Sci. Food Saf., 2, 139-162.

Singh, P. Wani A. A. and Saengerlaub, S., 2011. Nutr. Food Sci., 41, 249-260.

Smith Palmer, A., Stewart, J. and Fyfe, L. 2001. The potential application of plant essential oils as natural foods preservatives in soft cheese. Food Microbiology 18, 463-470.

Snuossi M, Trabelsi N, Ben Taleb S, Dehmeni A, Flamini G, De Feo V. 2016. Laurus nobilis, zingiber officinale and anethum graveolens essential oils: composition, antioxidant and antibacterial activities against bacteria isolated from fish and shellfish. Molecules. 21(10).

Solorzano-Santos, F.; Miranda-Novales, M.G. 2012. Essential oils from aromatic herbs as antimicrobial agents. Curr. Opin. Biotechnol. 23, 136-141.

Soto, V. C., González, R. E., Sance, M. M., \& Galmarini, C. R. (2016). Organosulfur and phenolic content of garlic (Allium sativum L.) and onion (Allium cepa L.) and its relationship with antioxidant activity. Acta Horticulturae, 1143(277-290).

Souza, E. L., Montenegro, Stamford, T. L. and Oliveira-Lima, E. 2006. Sensitivity of spoiling and pathogen food-related bacteria to Origanum vulgare L. (Lamiaceae) essential oil. Braz. J. Microb. 37:527-532.

Sreejayan, N. and Rao, M.N.A. 1994 Curcuminoids as potent inhibitors of lipid peroxidation. The Journal of Pharmacy and Pharmacology 46, 1013-1016.

Srinivasan, K. 2014. Antioxidant potential of spices and their active constituents (on line). Crit. Rev. Food Sci. Nutr. 54, 352-372. [CrossRef] [PubMed]

Stoilova, I., Krastanv, A., Stoyanova, A., Denev, P. and Gargova, S. 2007. Antioxidant activity of a ginger extract (Zingiber officinale). Food Chemistry 102, 764-770.

Subramonian, M., Sreejayan Rao, M.N.A., Devasagayam, T.P.A. and Singh, B.B. 1994. Diminuition of singlet oxygen induced D.N.A. damage by curcumin and related antioxidants. Mutation Research 311, 249-255.

Suhr, K.I. and Nielsen, P.V. (2003) Antifungal activity of essential oils evaluated by two different application techniques against rye bread spoilage fungi. Journal of Applied Microbiology 94(4), 665-674.

Sung S.-Y., L. T. Sin, T.-T. Tee, S.-T. Bee, A. R. Rahmat, W. A. W. A. Rahman, A.-C. Tan and M. Vikhraman, Trends Food Sci. Technol., 2013, 33, 110-123.

Tabak M, Armon R, Potasman I, Neeman I. In vitro inhibition of Helicobacter pylori by extracts of thyme. J Appl Bacteriol 1996; 80:667-72.

Tajkarimi MM, Ibrahim SA, Cliver DO. 2010. Antimicrobial herb and spice compounds in food. Food Control. 21(9):1199-1218.

Tajik, H., Tamaddonfard, E. and Hamzeh-Gooshchi, N., 2008. The effect of curcumin (active substance of turmeric) on the acetic acid-induced visceral nociception in rats. Pakistan journal of biological sciences PJBS 11: 312-314.

Talukder F. A., S. Islam, M. S. Hossain, M. A. Rahman, and M. N. Alam, 2004. "Toxicity effects of botanicals and synthetic insecticides on Tribolium castaneum (Herbst) and Rhyzopertha dominica (F.)," Bangladesh Journal of Environment Science, vol. 10, no. 2, pp. 365-371,

Tanvir, E. M., Md. Sakib Hossen, Md. Fuad Hossain, Rizwana Afroz, Siew Hua Gan,Md. Ibrahim Khalil, and Nurul Karim, 2017. Antioxidant Properties of Popular Turmeric (Curcuma longa) Varieties from Bangladesh. Journal of Food Quality, Article ID 8471785, 8 pages

Teixeira B., A. Marques, C. Pires, C. Ramos, I. Batista, J. A. Saraiva and M. L. Nunes, 2014. LWT-Food Sci. Technol., 59, 533-539.

Tripathi, A. K., Prajapati, V., Verma, N., et al. 2002. Bioactivities of the Leaf Essential Oil of Curcuma longa (Var. Ch-66) On Three Species of Stored Product Beetles (Coleoptera). J. Econ. Entomol. 95(1): 183-189.

Tohma H., İlhami Gülçin Ercan Bursal, Ahmet C. Gören, Saleh H. Alwase, Ekrem Köksal, 2016. Antioxidant activity and phenolic compounds of ginger (Zingiber officinale Rosc.) determined by HPLC-MS/MS. Food Measure, DOI 10.1007/s11694-016-9423-Z

Tunc, I., B. M. Berger, F. Erler, and F. Dagli, 2000. "Ovicidal activity of essential oils from five plants against two stored-product insects," Journal of Stored Products Research, vol. 36, no. 2, pp.161-168,

Tüfek, N.H., Altunkaynak, M.E., Altunkaynak, B.Z., \& Kaplan, S. 2015. Effects of thymoquinone on testicular structure and sperm production in male obese rats. Systems Biology in reproductive Medicine, 61(4), 194204.

USDA, 2014. Database for the Flavonoid Content of Selected Foods. Release 3.1. Available online:https://www.ars.usda.gov/ARSUserFiles/80400525/Data/Flav/Flav_R03-1.pdf (accessed on 30 May 2017).

Valero D, Valverde JM, Martínez-Romero D, Guillén F, Castillo S, Serrano M. 2006. The combination of modified atmosphere packaging with eugenol or thymol to maintain quality, safety and functional properties of table grapes. Postharvest Biology and Technology. 41(3):317-27.

Veluti, A., Sanchis, V., Ramos, A.J. and Marin, S. 2004. Effect of essential oils of cinnamon, clove, lemongrass, 
oregano and palmarosa on growth and fumonisin B1 production by Fusarium verticillioides in maize. Journal of the Science of Food and Agriculture 84(10), 1141-1146.

Verma A., Agarwal D., Dhanik J., Arya N. and Nand V., 2018. Antibacterial Efficacy and Cluster Analysis of Genotypic Extracts of Coriander Leaves and Seeds against Human Pathogenic Bacterial Strains. International Journal of Current Microbiology and Applied Sciences. ISSN: 2319-7706 Volume 7 Number 05

Victor G. L. Souza, João R. A. Pires, Érica T. Vieira, Isabel M. Coelhoso, Maria P. Duarte and Ana L. Fernando, 2018. Shelf Life Assessment of Fresh Poultry Meat Packaged in Novel Bionanocomposite of Chitosan/Montmorillonite Incorporated with Ginger Essential Oil. Coatings 8, 177; doi:10.3390/coatings8050177

Vijaylakhshmi V, Smith SC, Gamlath S. 2014. Consumer acceptability and antioxidant potential of probioticyogurt with spices. LWT-Food Science and Technology.; 55(1):255-262.

Viuda-Martos M, Ruiz-Navajas Y, Fernández-López J, Pérez-Álvarez JA. 2010. Effect of added citrus fibre and spice essential oils on quality characteristics and shelf-life of mortadella. Meat Science. 85(3):568-76.

Vrinda Menon K, Garg SR. 2001. Inhibitory effect of clove oil on Listeria monocytogenes in meat and cheese. Food Microbiology.;18(6):647-50.

Wangensteen, H., Samuelsen, A.B. and Malterud, K.E. 2004. Antioxidant activity in extracts from coriander. Food Chemistry 88(2), 293-297.

Wohlmuth, H., Leach, D.N., Smith, M.K. and Myers, S.P. 2005. Gingerol content of diploid and tetraploid clones of ginger (Zingiber officinale Roscoe). Journal of Agricultural and Food Chemistry 53(14), 57725778 .

Wolde T, Kuma H, Trueha K and Yabeker, 2018. Anti-Bacterial Activity of Garlic Extract against Human Pathogenic Bacteria. Journal of Pharmacovigilance, 6:1 DOI: 10.4172/2329-6887.1000253

Wu J., H. Liu, S. Ge, S. Wang, Z. Qin, L. Chen, Q. Zheng, Q. Liu and Q. Zhang, 2015. Food Hydrocolloids, , 43, $427-435$.

Yesiloglu, Y.; Audin, H.; Kilic, I. 2014. In vitro antioxidant activity of various extracts of ginger seed. Asian J. Chem. 25, 3573-3578.

Yano, Y., Satomi, M., Oikawa, H., 2006. Antimicrobial effect of spices and herbs on Vibrio parahaemolyticus. Int. J. Food Microbiol., 111(1), 6-11.

Yüncü, M., Şahin, M., Bayat, N., \& İbrahim, S. 2013. Çörek otu yağının sıçan karaciğer gelişimine etkisi. Gaziantep Medical Journal, 19(3), 180-184.

Zachariah, T.J., Mathew, P.A. and Gobinath, P. (2005) Chemical quality of berries from black pepper varieties grafted on Piper colubrinum. Journal of Medicinal and Aromatic Plant Sciences 27(1), 39-42. 